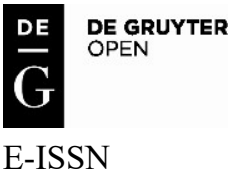

2450-8594

\title{
GLACIOTECTONICALLY DEFORMED LIGNITE DEPOSITS IN THE AREA BETWEEN LAGÓWEK AND SIENIAWA, WESTERN POLAND
}

\author{
Wojciech KOT ${ }^{1}$, Marek WIDERA \\ Adam Mickiewicz University, Poznań, Poland
}

\begin{abstract}
The Sieniawa Lignite Mine, situated between Łagówek and Sieniawa in western Poland, has been operating for nearly 150 years. This territory was strongly affected by the Scandinavian ice sheets during the Pleistocene. The depth of these deformations reaches the main and currently exploited lignite seam of Miocene age, the second Lusatian lignite seam (LLS-2). Analysis of drilling profiles and observations of the lignite opencast walls allow documentation of the diversity and abundance of glaciotectonic deformation structures within Neogene and Quaternary sediments, which include upright and recumbent folds, normal and reversed faults, complementary joint sets, injection structures as well as shear surfaces.
\end{abstract}

Keywords: lignite deposits, glaciotectonic deformations, Sieniawa Lignite Mine, western Poland

\section{INTRODUCTION}

Mining operations between Łagówek and Sieniawa in western Poland have been active for over 150 years (Fig. 1), first as underground and later as surface activities. In 1853, the lignite mine was first established by German owners in Sieniawa but exploitation on an industrial scale only began in 1873. Annual lignite production from this mine periodically reached $0.08 \mathrm{Mt}$ before World War II [3, $8,9]$. The mine was partially destroyed during the war and taken over by a Polish

${ }^{1}$ Corresponding author: Adam Mickiewicz University, Department of Environmental Geology,

B. Krygowskiego st 12, 61-680 Poznań, Poland, tel. +48618296013 
crew shortly thereafter. The Sieniawa Lignite Mine reactivated lignite production in 1950. Annual lignite production ranged between 0.002 and $0.2 \mathrm{Mt}$, reaching a maximum of $0.211 \mathrm{Mt}$ in 1982 . In recent years, lignite production has been less than $0.1 \mathrm{Mt}$ with $0.07 \mathrm{Mt}$ extracted in 2016 [9, 10]. Lignite was mined using the underground method until 1997. Surface exploitation of lignite commenced in 1979 and continues to present $[3,8,9]$. The location and order of the mined lignite saddles are shown in Fig. 1.

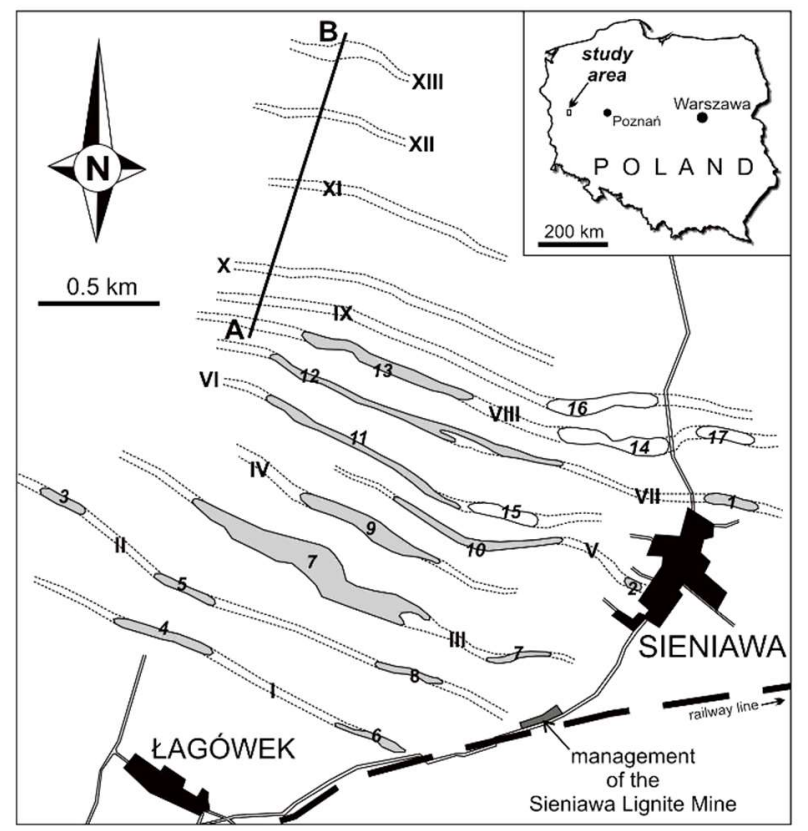

Fig. 1. Location map $[3,8,9]$; A-B - cross-section shown in Fig. 2; I-XIII - numbers of lignite saddles (anticlines); $\mathbf{1 - 1 7}$ - order of exploited lignite saddles; dotted lines elongation of lignite saddles; grey areas - underground mining (1-13); white areas surface mining (14-17)

More than 150 lignite occurrences have been documented in Polan d. However, only a few tens of them may be important for the Polish mining and electrical industries [7, 13]. At the end of 2016, the total minable geological resources amounted to $23.45 \mathrm{Gt}$, and $60.3 \mathrm{Mt}$ of lignite was exploited in that year [10]. Therefore, the aforementioned $0.07 \mathrm{Mt}$ mined by the Sieniawa Lignite Mine plays only a minor role in Polish lignite mining [13]. However, the lignite deposits located in Łagówek and Sieniawa are the most glaciotectonically disturbed lignite deposits in the world $[2,4,7,9,11,12,14]$.

Lignite deposits (saddles) are easily studied due to the fact that they have been exploited in shallow opencasts for years and will continue to be mined for many 
years to come. Hence, the current study presents the basic structural characteristics of the numerous and morphologically varied deformations in the area at both the macro- and mesoscale.

\section{DATA AND METHODS}

Cross-sections included in this study are based on borehole data obtained from the archive of the Sieniawa Lignite Mine. A large number of borehole profiles were initially analysed, but only a dozen of them were selected in order to construct four cross-sections through the recently exploited lignite saddles IX and VIII. These cross-sections reveal the macroscale glaciotectonic structures in the region. Mesoscale glaciotectonic deformation structures were observed in the opencasts that belonged to the Sieniawa Lignite Mine in 2010-2015. At this time, lignite from saddle IX (already closed) and VIII (currently operating) was mined successively. During the field studies, the most interesting structures were observed, measured and documented photographically. Moreover, the elongation of the lignite anticlines (saddles) were measured in order to reconstruct the direction of ice sheet movement.

\section{GEOLOGICAL SETTING}

In the Lagówek-Sieniawa territory, the top of the sub-Cenozoic basement is built of marls and limestones of Cretaceous age. Palaeogene sediments present evidence of the presence of early Oligocene deposits (i.e., glauconitic sands of marine origin), which only occasionally take part of the examined glaciotectonic disturbances (Fig. 2).

The study area and most of central Poland was subjected to regional uplift during the late Oligocene [11, 15]. Mineral and organic sediments were deposited from the early to mid-Miocene. The second Lusatian lignite seam (LLS-2) accumulated under relatively steady and long-lasting subsidence conditions in the midMiocene. These lignites and accompanying Neogene-age deposits were strongly affected by glaciotectonics (Fig. 2).

Similarly, Quaternary glaciogenic deposits of mostly Pleistocene age were significantly deformed by the Scandinavian ice sheets. Glaciation events in this region are represented as three groups: South-Polish - Elsterian; Mid-Polish Saalian and North-Polish - Weichselian. The majority of Pleistocene sediments include glacial tills, glaciofluvial sands, gravels and lenses of glaciolacustrine silts (Fig. 2) $[3,8,15]$. 


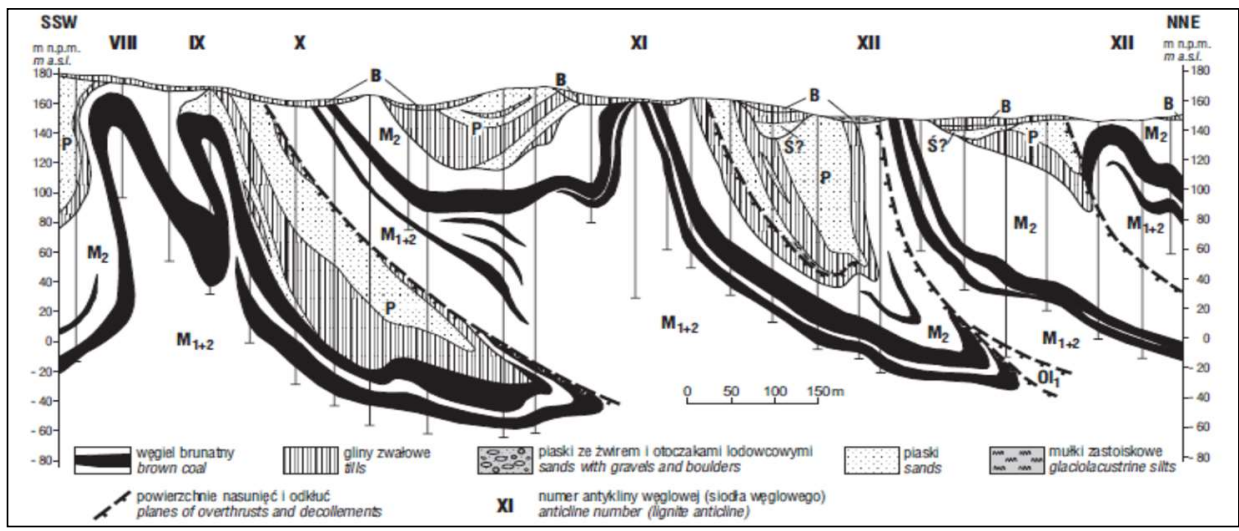

Fig. 2. Cross-section through the study area [15]; $\mathrm{Ol}_{1}-$ Lower Oligocene, $\mathrm{M}_{1+2}-$ Lower and Middle Miocene, $\mathrm{M}_{2}$ - Middle Miocene, $\mathrm{P}$ - South-Polish glaciations (Elsterian),

Ś - Mid-Polish glaciations (Saalian), B - North-Polish glaciations (Weichselian); brown coal $=$ lignite of the $2^{\text {nd }}$ Lusatian lignite seam (LLS-2); for location see Fig. 1

\section{MACROSCALE GLACIOTECTONIC DEFORMATIONS}

The macroscale deformation structures are most visible on cross-sections that contain sections from one or a few lignite anticlines and/or synclines. It is worth noting that only the highest parts of lignite saddles, located above the first groundwater level, are available for direct observations.

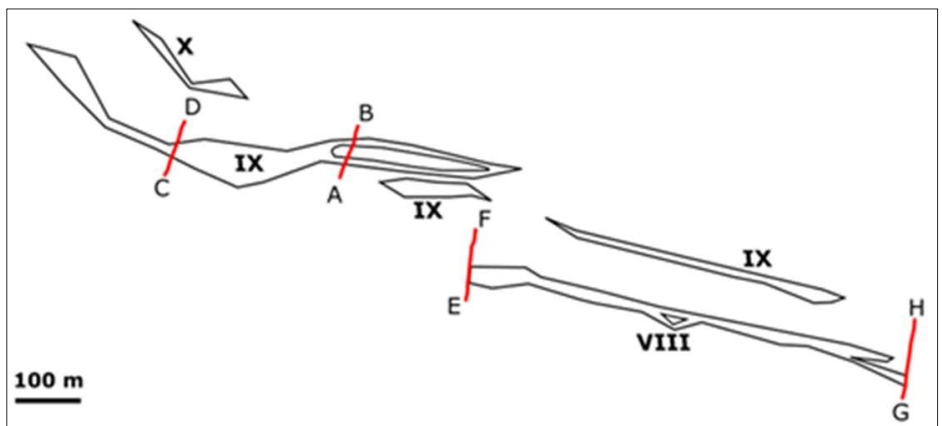

Fig. 3. Location of the cross-sections A-B, C-D, E-F and G-H through the lignite saddles IX and VIII, respectively (Figs. 4, 5)

The aforementioned glaciotectonic deformation structures are divided into folds and thrusts. Four simplified cross-sections through the most recently extracted lignite saddles IX and VIII are presented in Figs. 3-5. 


\subsection{Folds}

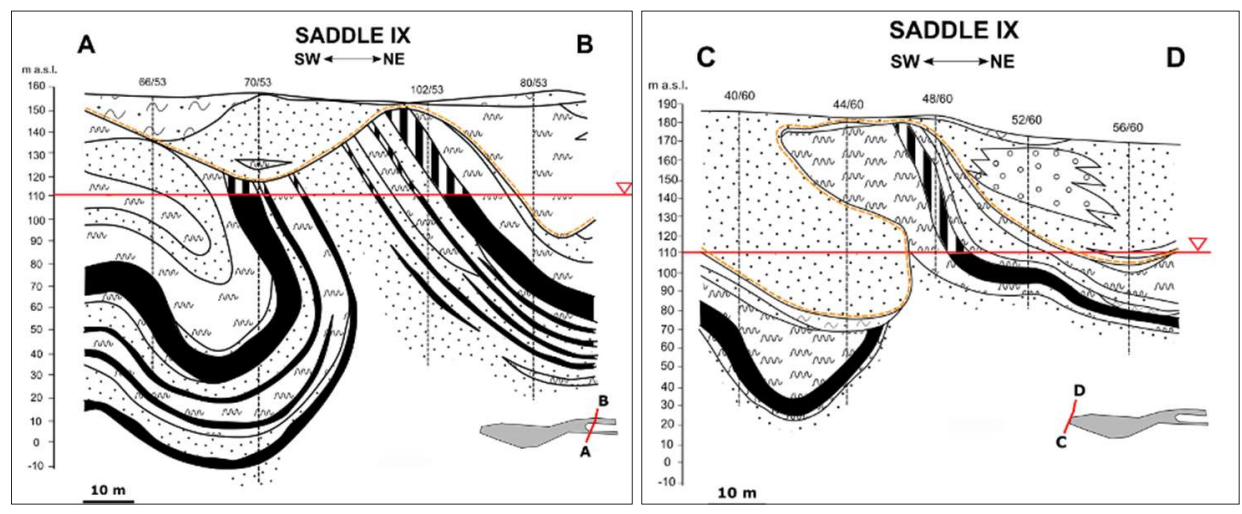

Fig. 4. Cross-sections through the lignite saddle IX (Sieniawa Lignite Mine) [8]; blacklignite, black and white stripes - exploited parts of saddles; for location see Fig. 3

All geological cross-sections show glaciotectonic deformation structures of relatively simple geometry. In general, these structures are upright with asymmetrical to slightly overturned folds (Figs. 4, 5). The LLS-2 has an average true thickness of 10-20 m, however, its apparent thickness exceeds $30-50 \mathrm{~m}$ in the uppermost anticlinal parts of folds. The depth of this deformation reaches more than $200 \mathrm{~m}$ from the ground surface $[2,3,11,12]$.

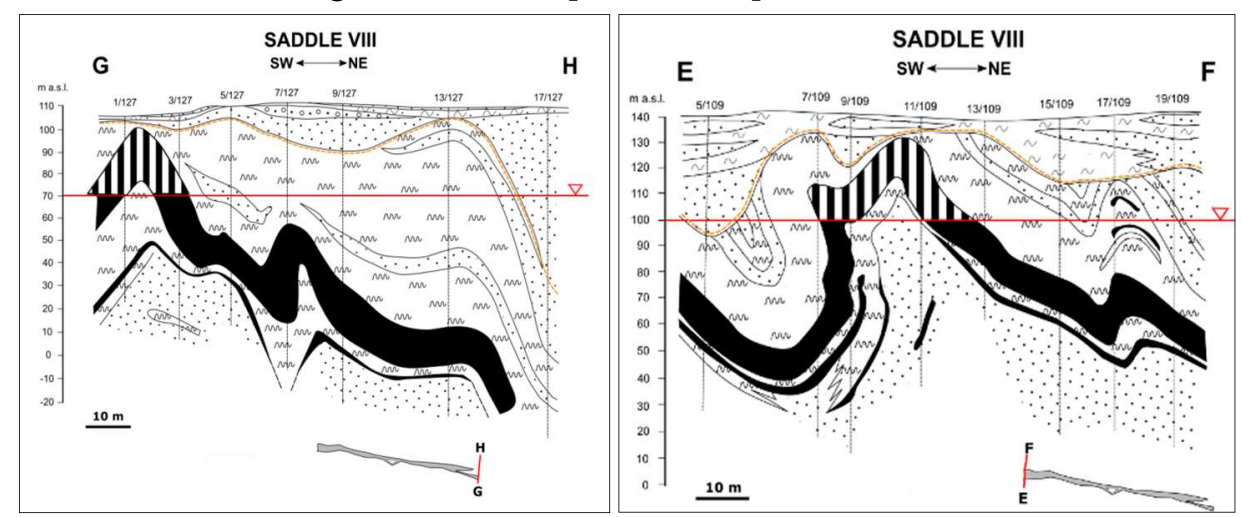

Fig. 5. Cross-sections through the lignite saddle VIII (Sieniawa Lignite Mine) [8]; for location see Fig. 3 and for explanations see Fig. 4

On the other hand, the lignites are clearly folded in the range of 100-150 m. The difference between the two lignite saddles is that the continuity of the lignite seam in saddle IX is interrupted by Quaternary erosion processes (Figs. 4, 5). 


\subsection{Thrusts}

Macroscale thrusts are also common in the study area and are presented on numerous cross-sections in the literature [2-5, 11-12, 14-15], as well as those included here (Figs. 2, 10c). These thrusts represent the final stage of the aforementioned fold development. Simply speaking, the folded deposits are sliced and/or imbricated under conditions of further horizontal compression $[1,5,6]$. Thus, the continuity of layers, including those in the investigated lignite seam, is broken (Figs. 2, 10c).

\section{MESOSCALE GLACIOTECTONIC DEFORMATION STRUCTURES}

\subsection{Folds}

Mesoscale folds outcrop clearly in the Sieniawa lignite opencast mine although only the uppermost, positive segments of the lignite folds (i.e., anticlines or saddles) are available for direct observation (Figs. 6, 7). The folds are mostly upright and symmetrical, and their axial zones are often made of lignite (Figs. 6, 7a, 7c). In some cases, the axial zones are made of sands that underlie LLS-2 (Fig. 7b). Additionally, the internal structure of the folds is disturbed and the lignite layers are sometimes very strongly folded (Fig. 6b).
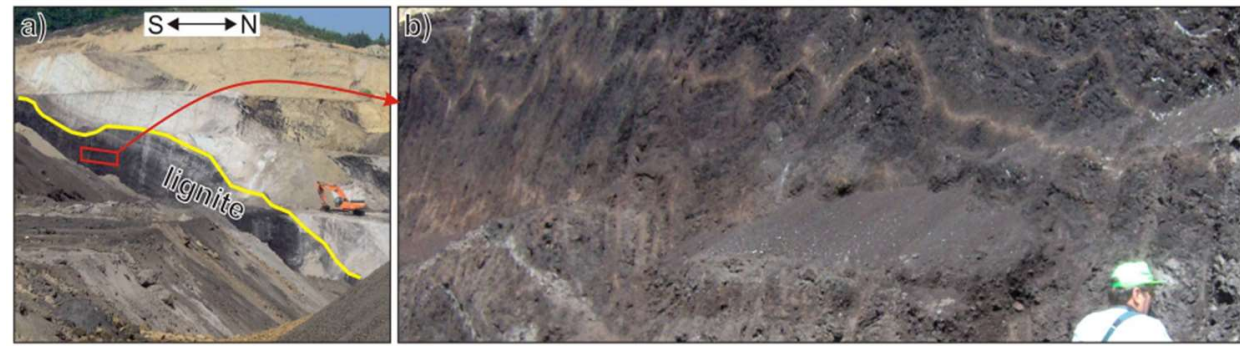

Fig. 6. Folded lignites of LLS-2 in the saddle IX (2010, Sieniawa Lignite Mine): a) broad view of the upright fold, b) internally disturbed the fold structure; note strongly deformed the lighter layers of the weathered lignite lithotype

The Quaternary sediments are also folded, however, in contrast to the aforementioned folds of the Neogene deposits, these folds are much more overturned and even recumbent (Fig. 8). The presented example (Fig. 8) shows two levels of glacial tills. Because of the colour contrast between the grey (Saalian) and brown (Weichselian) tills, the geometry of the recumbent fold and its internal structure are clearly visible (Fig. 8). 
GLACIOTECTONICALLY DEFORMED LIGNITE DEPOSITS IN THE AREA BETWEEN 165 ŁAGÓWEK AND SIENIAWA, WESTERN POLAND
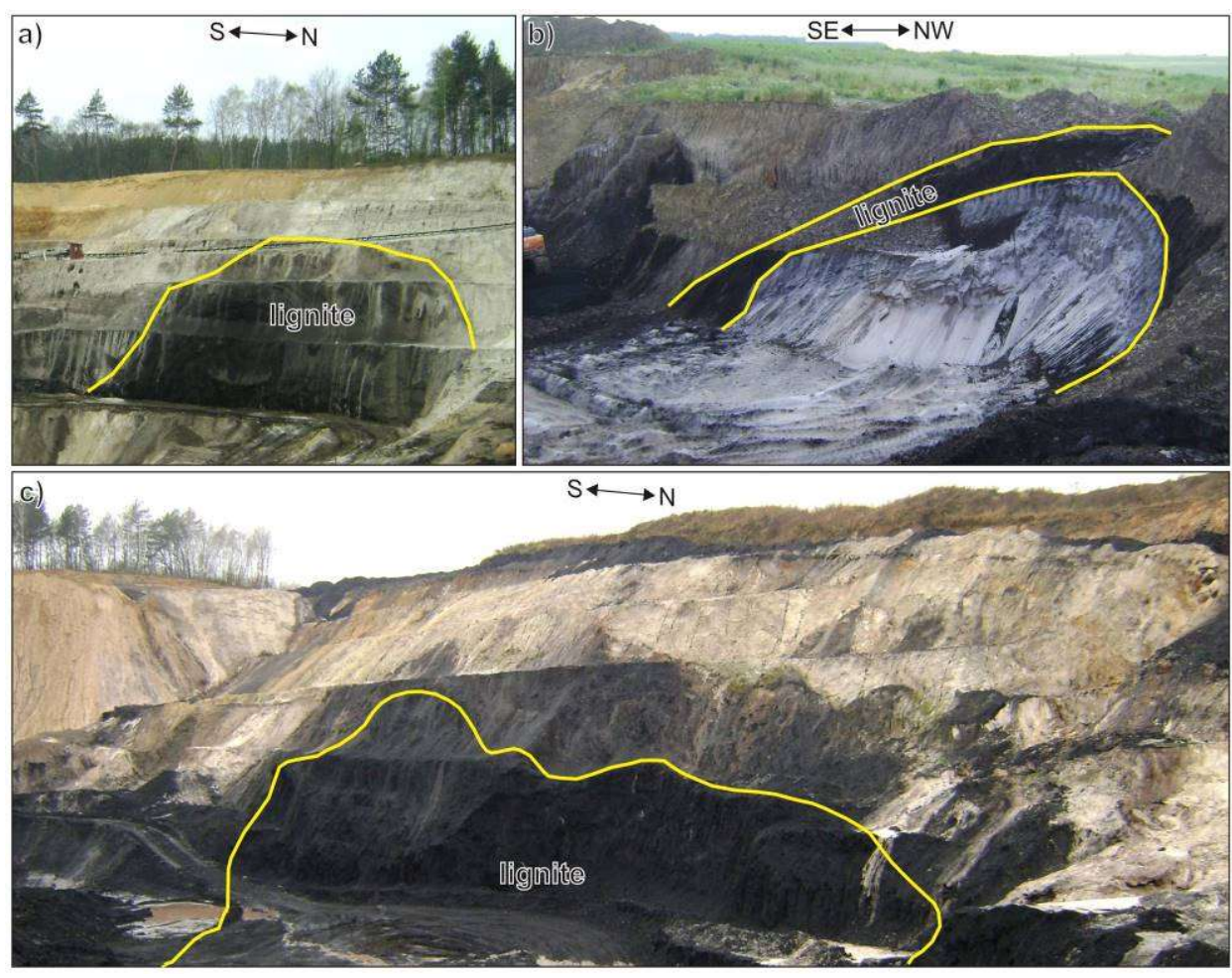

Fig. 7. Folded lignites of LLS-2 in the saddle VIII (2014, Sieniawa Lignite Mine): a) and c) the upright folds built of lignites, b) the upright fold built of sands and lignites

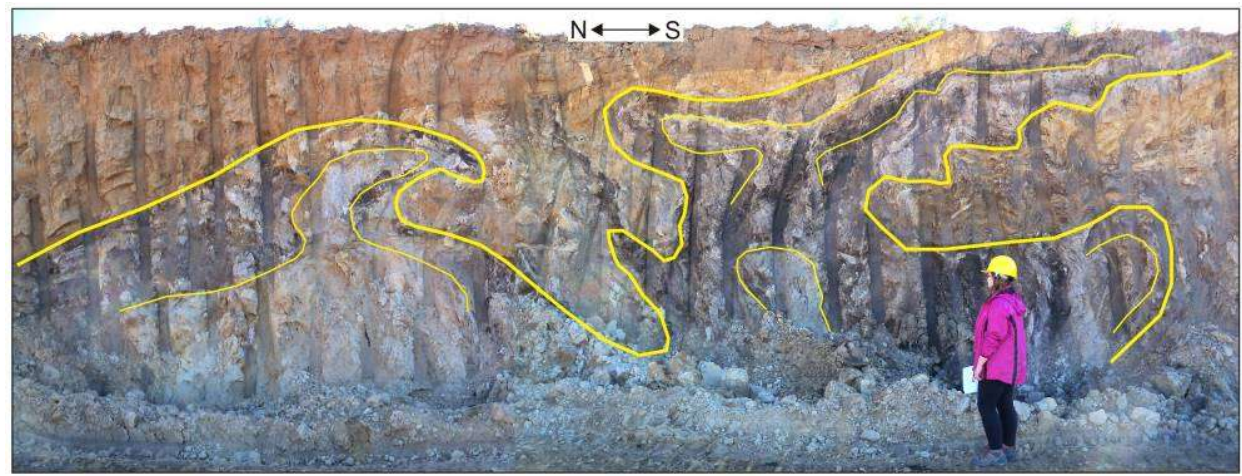

Fig. 8. Recumbent folds of the Quaternary deposits in the Sieniawa opencast (2015, Sieniawa Lignite Mine) 


\subsection{Faults and thrusts}

In addition to the glaciotectonic discontinuous deformation structures in the Sieniawa lignite opencasts, various types of faults were also observed (Fig. 9). Due to the compressive nature of glaciotectonics, reverse faults are obviously more common than normal faults. Both types occurred within the Neogene and Quaternary, as well as within the mineral and organic sediments (Fig. 9).
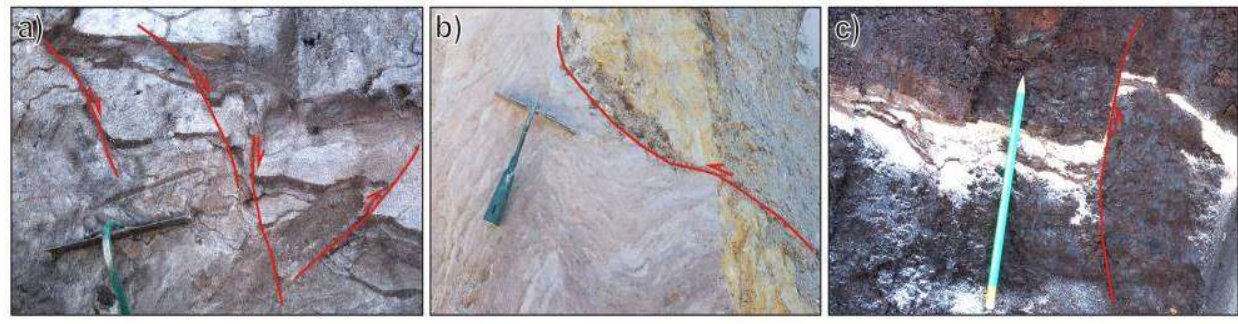

Fig. 9. Normal and reverse faults in the Sieniawa opencast: a) faulted the Neogene sands and silts, b) faulted the Quaternary sands and gravels, c) faulted the Neogene lignites with thin sandy intercalation

Thrusts are difficult to observe and document in the field because they define the limits of lignite mining, but fortunately, this was achieved in saddle VII of the Sieniawa lignite opencast in 2015 (Figs. 10a, 10b). This thrust plane is the boundary between the Quaternary sands (footwall) and Neogene lignites (hanging wall), and may correspond to the situation shown on the geological section through saddle IX in Fig. 10c.
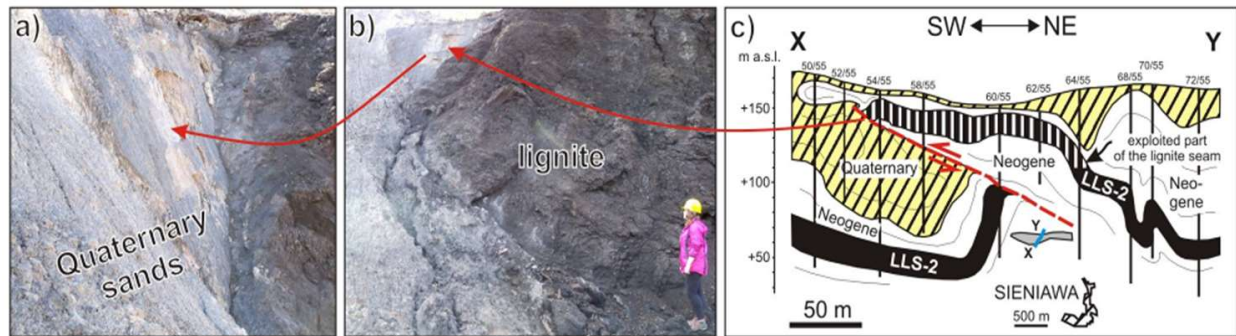

Fig. 10. Thrust plane in the Sieniawa opencast: a) close-up view of the thrust plane,

b) broad view of the thrust plane, c) possible the thrust plane location; the Neogene lignites are the hanging wall, the Quaternary sands are the footwall 


\subsection{Complementary joint sets}

Two joint (break, fracture, shear) sets that intersect symmetrically about a plane or line are called complementary joint sets. Such sets of shears, which intersect at an angle of about $60^{\circ}$, were documented in the Sieniawa lignite opencast (Fig. 11a) and indicate that the principal stress was almost vertical in this case. The formation of the fold within which these joints are present was therefore similar to that of the salt diapirs (i.e., by the process of bending) [6].

\subsection{Injection structures}

Injection structures are rather rare among glaciotectonic deformation, however, such structures are known from lignite-bearing areas [5]. The characterised injection is composed of lignite and surrounded by sands that originally underlay LLS-2 (Fig. 11b). A compression mechanism is suggested to have formed this injection due to its glaciotectonic origin [8]. The formation of the injection structures was similarly explained in eastern Germany [5].

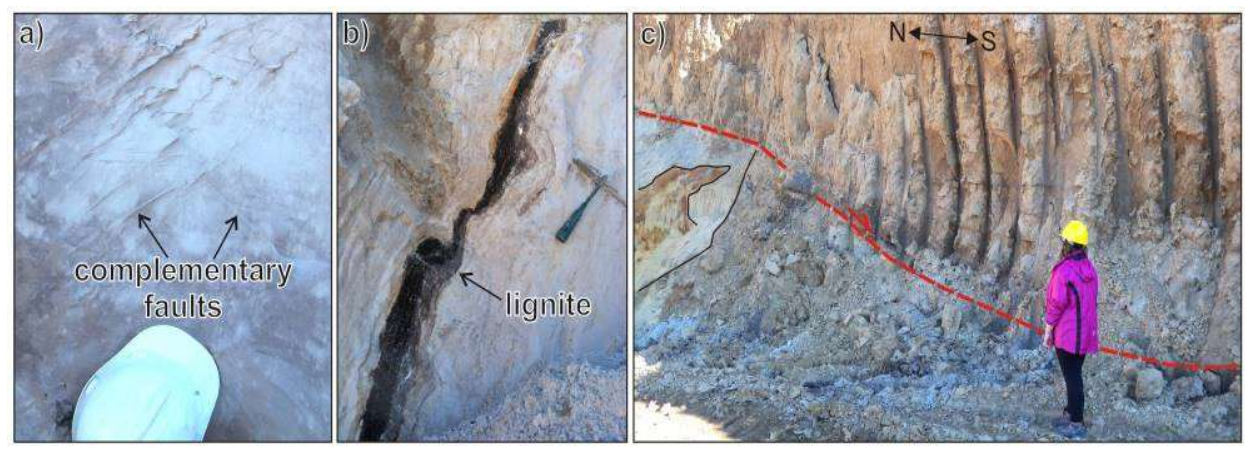

Fig. 11. Glaciotectonic deformations in the Sieniawa opencast: a) complementary joint sets in the Neogene sands, b) injected lignite layer within the Quaternary sands and silts, c) shear surface between the sediments of the Mid-Polish (grey tills white-brown sands and gravels) and North-Polish (brown tills) glaciations

\subsection{Shear surfaces}

The last large-scale structure is a nearly horizontal shear surface, which determines the boundary between the two tills of the mid-Polish and north-Polish glaciations (Fig. 11c). Furthermore, the steeply arranged sands and gravel are clearly cut by the shear surface. Its position indicates the contact zone between the top layers of the pre-glacial surface and the base of an advancing ice sheet. In other words, this is a zone where the simple shear occurred $[1,6]$. 


\subsection{Direction of ice sheet movements}

The direction of the Scandinavian ice sheet movement was determined according to the orientation of the macroscale glaciotectonic deformation in the study area. The elongation of the lignite saddles (50 segments) was taken into account. The mean azimuth of nine saddle axes was first graphically drawn, then measured and finally calculated statistically (Tab. 1).

Table 1. The strike of the lignite saddles based on 50 measurements [8]

\begin{tabular}{|c|c|c|c|c|c|c|c|c|c|}
\hline $\begin{array}{l}\text { Lignite } \\
\text { saddle } \\
\text { number }\end{array}$ & VIII & IX & X & XI & XII & XIII & XIV & XV & XVI \\
\hline $\begin{array}{c}\text { Mean } \\
\text { azimuth of } \\
\text { the saddle } \\
\text { axis }\end{array}$ & $\begin{array}{l}105- \\
285^{\circ}\end{array}$ & $\begin{array}{l}113- \\
293^{\circ}\end{array}$ & $\begin{array}{l}118- \\
298^{\circ}\end{array}$ & $\begin{array}{l}111^{-} \\
291^{\circ}\end{array}$ & $\begin{array}{l}109- \\
289^{\circ}\end{array}$ & $\begin{array}{l}116- \\
296^{\circ}\end{array}$ & $\begin{array}{l}108- \\
288^{\circ}\end{array}$ & $\begin{array}{l}117- \\
297^{\circ}\end{array}$ & $\begin{array}{l}111^{\circ} \\
291^{\circ}\end{array}$ \\
\hline
\end{tabular}

Calculations were made according to the fundamental assumption that the ice sheet transgression was perpendicular to the strike of the lignite saddles (i.e., anticlines) $[1,5,6]$. Thus, the direction of the ice sheet advancing to the area between Lagówek and Sieniawa was calculated by adding and subtracting $90^{\circ}$ from the results listed in Table 1. The results indicate that the Scandinavian ice sheet or ice sheets came to the study area from the azimuth $23^{\circ}$ to $203^{\circ}$, which is approximately NNE to SSW $[8,9]$.

\section{CONCLUSIONS}

This study is exclusively dedicated to glaciotectonic deformations in the area between Łagówek and Sieniawa in western Poland. The following conclusions can be drawn based on the analysis of boreholes and walls of the Sieniawa lignite opencasts.

First, the study area was affected by Scandinavian ice sheets during the Pleistocene. This occurred at least a few times in episodes representing the SouthPolish (Elsterian), Mid-Polish (Saalian) and North-Polish (Weichselian) glaciations.

The Neogene and Quaternary sediments were strongly disturbed glaciotectonically to a depth exceeding $200 \mathrm{~m}$. The deformation reached the Miocene-aged LLS-2, which has been continuously mined for nearly 150 years. Both archival data and field observations allowed identification of numerous glaciotectonic deformation structures at the macro- and mesoscale. These structures include upright and recumbent folds, normal and reversed faults, complementary joint sets, injection structures and shear surfaces. 
The direction of the Scandinavian ice sheet movement was also determined based on the orientation of lignite saddles. The ice sheet or sheets advanced into the study area from approximately the NNE to SSW direction (azimuth $23^{\circ}$ to $203^{\circ}$ ) $[8,9]$.

In summary, this paper provides evidence that lignite deposits in the ŁagówekSieniawa area are completely disturbed by glaciotectonics. It is likely that these deposits are the world's most glaciotectonically deformed lignite deposits under current exploitation. The examined deposits can therefore be distinguished as a separate genetic type, i.e. glaciotectonic type of lignite deposit $[2,7,12]$.

\section{ACKNOWLEDGEMENTS}

This study is part of the first author's MSc thesis. The Sieniawa Lignite Mine in the person of its director-in-chief, Andrzej Bik, is kindly thanked for permitting to conduct archive and field work in the lignite opencasts. We extend our sincere gratitude to Jerzy Jarosz and Michał Dziekan, the geologists from the Department of Geology in this mine, for their hospitality and help.

\section{REFERENCES}

1. Aber J.S., Ber A.: Glaciotectonism. Developments in Quaternary Science 6, Amsterdam, Elsevier 2007.

2. Ciuk E.: Types of brown coal deposits within coal-bearing formations of continental Tertiary of Poland, 23rd Geological Congress, Prague, (1968) 119-134.

3. Dokumentacja geologiczna złoża węgla brunatnego Sieniawa 1, wykonana w oparciu o umowę nr 02-020 z dnia 14.05.2002 r., Przedsiębiorstwo Geologiczne we Wrocławiu „PROXIMA” S.A., Wrocław, 2002.

4. Dyjor S.: Zaburzenia glacitektoniczne na obszarze Ziemi Lubuskiej. I Sympozjum Glacitektoniczne, Zielona Góra, Wydawnictwo Uczelnianie Wyższej Szkoły Inżynierskiej im. Jurija Gagarina w Zielonej Górze, (1974) 71-90.

5. Eissmann L.: Quaternary geology of eastern Germany (Saxony, SaxonAnhalt, South Brandenburg, Thuringia), type area of the Elsterian and Saalian Stages in Europe, Quaternary Science Reviews, 21 (2002) 1275-1346.

6. Jaroszewski W.: Rozważania geologiczno-strukturalne nad geneza deformacji glacitektonicznych. Annales Societatis Geologorum Poloniae, 61 (1991) 153-206. 
7. Kasiński J.R., Piwocki M.: Low rank coals in Poland: prospection, mining, progress, In: Jureczka J., Podemski M. (Eds.), Proceedings of the IV European Coal Conference, Polish Geological Institute Special Papers, 7 (2002) 18-30.

8. Kot W.: 2017. Deformacje glacitektoniczne na obszarze górniczym KWB Sieniawa Sp. z o.o., Praca magisterska, Archiwum Instytutu Geologii UAM, Poznań, (2017) 1-69.

9. Kot W., Widera M.: The area between Łagówek and Sieniawa in western Poland: the most glaciotectonically deformed lignite deposits in the world. CGE-2017 - 2nd Second International Conference "Challenges in Geotechnical Engineering". November $20^{\text {th }}-23^{\text {th }} 2017$, Kyiv, Ukraine (2017) 46-47.

10. Szuflicki M., Malon A., Tymiński M. (Eds.): Bilans zasobów złóż kopalin w Polsce wg stanu na 31.12.2016. Państwowy Instytut Geologiczny, (2017) 1-475. http://geoportal.pgi.gov.pl/surowce.

11. Widera M.: Changes of the lignite seam architecture - a case study from Polish lignite deposits, International Journal of Coal Geology, 114 (2013) 60-73.

12. Widera M.: Genetic classification of Polish lignite deposits: A review, International Journal of Coal Geology, 158 (2016) 107-118.

13. Widera M., Kasztelewicz Z., Ptak M.: Lignite mining and electricity generation in Poland: The current state and future prospects, Energy Policy, 92 (2016) 151-157.

14. Widera M.: Tectonic and glaciotectonic deformations in the areas of Polish lignite deposits, Civil and Environmental Engineering Reports, (2017), in this volume.

15. Winnicki J.: Wptyw środkowoplejstoceńskich struktur glacitektonicznych i rynien subglacjalnych na rzeźbę w pótnocnej części Pojezierza Lubuskiego (zachodnia Polska), Przegląd Geologiczny, 52 (2004) 1144-1150.

\section{ZDEFORMOWANE GLACITEKTONICZNIE ZŁOŻA WĘGLA BRUNATNEGO NA OBSZARZE MIĘDZY ŁAGÓWKIEM A SIENIAWĄ, POLSKA ZACHODNIA}

\section{Streszczenie}

Obszar zachodniej Polski poddany został destrukcyjnej działalności kolejno zlodowaceń: południowo-, środko- i północnopolskich. Doprowadziły one do deformacji zarówno osadów czwartorzędowych, jak i neogeńskich, w tym węgli brunatnych 2. łużyckiego pokładu, który od blisko 150 lat jest eksploatowany przez KWB Sieniawa. Jego dobre rozpoznanie przy pomocy gęstej siatki wierceń oraz wydobycie z siodeł węglowych, tj. części antyklin położonych powyżej pierwszego poziomu wód podziemnych, pozwoliły 
na udokumentowanie licznych i bardzo zróżnicowanych morfologicznie deformacji glacitektonicznych. $\mathrm{Na}$ obszarze poddanym badaniom, zlokalizowanym między Łagówkiem a Sieniawą, stwierdzono dotychczas aż 27 takich siodeł węglowych. Są to makroskalowe deformacje wykształcone w postaci różnego typu fałdów i nasunięć, które są widoczne przede wszystkim na przekrojach geologicznych. Natomiast mezoskalowe deformacje glacitektoniczne można obserwować bezpośrednio w odkrywkach KWB Sieniawa. Należą do nich: fałdy stojące, pochylone i leżące, uskoki normalne i odwrócone, spękania komplementarne, struktury iniekcyjne i powierzchnie ścięcia spągowego. Powstanie wymienionych struktur deformacyjnych wyjaśniono zadowalająco przy pomocy tzw. statyczno-kinetycznej koncepcji powstawania deformacji glacitektonicznych W. Jaroszewskiego (1991). Ponadto, na podstawie rozciągłości makrodeformacji (fałdów i nasunięć) obliczono, że skandynawskie lądolody w plejstocenie nasuwały się na obszar położony między Łagówkiem a Sieniawą w przybliżeniu z NNE (azymut $23^{\circ}$ ) na SSW (azymut $203^{\circ}$ ).

Słowa kluczowe: złoża węgla brunatnego, deformacje glacitektoniczne, KWB Sieniawa, zachodnia Polska

Eitor received the manuscript: 02.03 .2018 